\title{
KÖNYVJELZÖ
}

\section{BUDAY-SÁNTHA ATTILA: A BALATON-RÉGIÓ FEJLESZTÉSE - DEVELOPMENT ISSUES OF THE BALATON REGION}

\author{
(Saldo, Budapest, 2007, 204 o.) \\ BARTHA JÚLIA
}

A Balaton minden magyar ember számára egyszerre jelenti ugyanazt - Palóczi Horváth Ádảm ${ }^{1}$ találó szavaival élve a Magyar Tengert - és valami egyénit, személyeset, hiszen emlékeink között mindannyian őrizzük a magunk képét, történetét a Balatonról. A Balaton közös értékünk, emlékünk, közös jelen tapasztalásunk. Problémái, nehézségei - pl. alacsony vízállás - éppúgy közel állnak hozzánk, mint hívogató, megőrzött és megőrzendô értékei - pl. a táj, a víz, néphagyomány, bor - akár turistaként, akár elkötelezett kutatóként, természetvédőként közelítünk felé. Tudományos érdeklődéssel fordult a Balaton felé Buday-Sántha Attila is, akinek életét, szakmai pályáját szinte végigkíséri a tó és környéke. A nyolcvanas évek elejétől napjainkig született tanulmányaiban folyamatosan nyomon követhetö a Balaton körül folyó agrárgazdaság helyzete, annak környezetvédelmi vonatkozásai - az egyes mủvelési, talajhasználati, állattenyésztési módok hatása a Balaton és vízgyüjtője érzékeny ökoszisztémájára -, az iđőközben bekövetkezett változások és a térség fejlesztési lehetőségeinek alakulása.

Most megjelent könyvében Buday-Sántha Attila - talán a sok évtizedes munka összefoglalásaként, megkoronázásaként - átfogó elemzést készít a Balaton Kiemelt Üdülökörzetet, más néven Balaton régiót érintő legfontosabb kérdésekről. Célja feltárni és bemutatni a térség - mint szerves egység - számára adódó fejlödési, fejlesztési lehetőségeket, és mindeközben eloszlatni számos, a Balatonnal kapcsolatos tévhitet. Ehhez azonban ismerni kell múltat és jelent, adottságokat és lehetőségeket. A könyv szerkezete is ezt a logikát követi: először a tavat és a környezetét jellemző, legfontosabb általános információkkal - természetföldrajzi helyzet, a tó története ismerteti meg az olvasót, majd a jelenlegi társadalmi-gazdasági helyzet kialakulásáért felelős tényezőkkel és a térség gazdaságával foglalkozik részletesen. A jelenlegi helyzet ismertetésekor a szerző a Balatonról és környezetéről, mint komplex, természeti-gazdasági-társadalmi egységrỏl gondolkodik, objektivitásra törekszik, és nem riad meg a kritikai észrevételek megfogalmazásától. A térség egyik legalapvetőbb jellemzőjeként a megkésettséget, elmaradottságot említi. Megkésettnek bizonyulnak 
az infrastrukturális fejlesztések, elmaradottnak a tárgyi feltételek és sajnos a népesség turisztikai felkészültsége is. Fontos, hogy mindez nem feltétlenül az ország más területeihez viszonyított elmaradottság, nem átlag alatti teljesítés, ám az ország turisztikailag kiemelt desztinációjaként mindezek a jellemzök, hiányosságok a nemzetközi megmérettetés során felerösödve jelentkeznek, hiszen a turista nem csak a Balatonról, de egyben az országról is képet alkot rövid itt tartózkodása során.

A térség másik alapvető jellemzője a tó modern kori történelmét végigkísérő érdekütközésekböl ${ }^{2}$, irányitási megosztottságból ${ }^{3}$ adódó belső feszültség, amely igen csak megnehezítette a tó és környezete komplex egységként történö kezelését. A térség hatékonyabb fejlesztéséhez tehát kétség kívül szükség lenne a célok és érdekek összehangolására. Más kérdés, hogy a part menti és a háttértelepülések közötti fejlettségbeli különbség olyan mértékü, amelyet önmagában egy közigazgatási egység nem lenne képes feloldani. Ezt igazolják az immár egy évtizede fejlesztési státuszú régióként müködő ,egységes” Balaton régió tapasztalatai is, amely bár önálló testülettel ${ }^{4}$ büszkélkedhet, müködését egyrészt a még mindig fennálló irányítási megosztottság és érdekkülönbségek, másrészt a korlátozottan rendelkezésre álló önálló bevételek nehezítik.

Az önálló, jövőbeli fejlesztési irányvonalakra rámutató fejezet - ahogy az egész könyv - realitásokon alapul, józanul, kellő távolságból tekint az egész térségre, annak jövőbeli lehetőségeire. A Régió egyediségét, legnagyobb természeti értékét és egyben gazdasági alapját a víz jelenti. A Balaton a több száz éves emberi tevékenység (mocsárlecsapolás, partfalak építése, Zala szabályozása, környező erdők kivágása) eredményeként már az 1860-as évekre elvesztette természetes jellegét, mára egy sérülékeny, az emberi aktivitásoknak, tudatosságnak kiszolgáltatott, szabályozott, „természetszerü” tóvá vált. Egyik legfontosabb feladat, kiinduló pont ennek a „természetszerủ állapotnak” a megőrzése és ésszerủ fejlesztése. A térség gazdaságát napjainkban és minden bizonnyal a jövőben is az idegenforgalom mozgatja. A Régió területe azonban túl nagy ahhoz, hogy pusztán a turizmus képes legyen a háttértelepülések gazdaságának megfelelö dinamizálására. Törekedni kell ezért ennek a sérülékeny és fơként a part menti településekre koncentrálódó szerkezetnek az ellensúlyozására, amelyre leginkább a turizmust segítő, kiegészítő szolgáltatások, illetve a háttértelepüléseken alternativ turizmus ágak - pl. lovas, természetjáró turizmus -, ipari, mezőgazdasági egységek alkalmasak. A mezőgazdaság szerepe a turizmus szempontjából nem csak azért kiemelt, mert képes lenne ellátni a helyi piacokat áruval, - amit jelenleg a vertikum szereplöi közötti kapcsolat hiányában a pesti nagybani piac, illetve alföldi termelök oldanak meg -, mert sajátos termékkínálatával (pl. szőlö, bor) képes jellegzetes kiegészitő programot nyújtani a vendégek számára, hanem azért is, mert egy fejlett, nemzetközi turizmus elképzelhetetlen kulturálatlan tájban. Megtalálja helyét a fejlesztési feladatok között a napjaink üzleti életét mozgató marketing is, melynek egyik legfontosabb feladata a Balaton egységes megjelenítésének, a 'balatoni' jellegadó márkanév kialakulásának, erősítésének támogatása. Ám, ahogy más fejlesztési feladat, a balatoni image formálása is csak a szereplök összefogásával lehet eredményes. A fejezetet a szerző javaslatai, összeg- 
zése zárja, amely immár a szükséges ismeretek birtokában lévő olvasót lényegre törően szembesíti a problémákkal és megoldási lehetőségekkel.

A könyv egyik legszembetünőbb tipológiai jellemzỏje a szöveg hasábokra tördelt szerkesztése, amelyet a kiadvány kétnyelvüsége indokol. Minden oldalon párhuzamosan fut egymás mellett a szinte sorra pontosan szinkronba hozott magyar és angol nyelvủ szöveg, amely nagyban segíti a követhetőséget, és komoly fordítói és szerkesztői precizitásra vall. A könyv stílusa gördülékeny, kellő tudományossága mellett olvasmányos, ezért segítséget, szórakozást nyújthat a szakmai ismeretekkel kevésbé rendelkező, ám a Balaton iránt érdeklődők számára is. A könyv tartalmát a tematizált szerkezet jól tanulhatóvá, és ezzel számon kérhetővé teszi, így oktatási segédletként is kitủnően megállhatja a helyét bizonyos érintett szemináriumok esetében. A könyv lehetséges felhasználási területeit és olvasóbázisát kétnyelvüsége még tovább növeli.

\section{Jegyzetek}

${ }^{1}$ Balatonfüreden élő és alkotó neves ősünk, Pálóczi Horváth Ádám a 17. század végén Holmi c. kötetének verseiben nevezte elöször a Balatont Magyar Tengernek.

${ }^{2}$ A szerző érzékletes példákat hoz az egyes szereplők - mint például természetvédők, hatóságok, telektulajdonosok - szüklátókörüségéböl adódó problémákra, konfliktushelyzetekre, amelyek végül sem az egyik, sem a másik fél érdekeit nem szolgálják.

${ }^{3}$ Jelenleg 14 kistérség, három megye és a három megyét magában foglaló statisztikai-tervezési régió 'osztozik' a területen.

${ }^{4}$ Balaton Fejlesztési Tanács és az operativ feladatokat ellátó Balatoni Integrációs Fejlesztési Ügynökség. 
Tér és Társadalom 22. évf. 2008/2. 229-234. p.

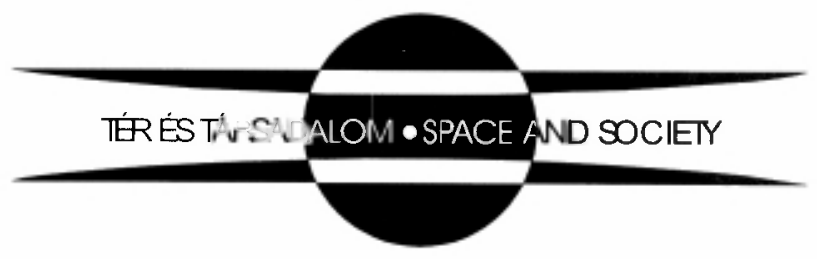

